\title{
Serine/Threonine-Protein Kinase 33
}

National Cancer Institute

\section{Source}

National Cancer Institute. Serine/Threonine-Protein Kinase 33. NCI Thesaurus. Code C94751.

Serine/threonine-protein kinase 33 (514 aa, $\sim 58 \mathrm{kDa}$ ) is encoded by the human ST K33 gene. This protein is involved in phosphorylation of serine or threonine-containing substrates. 